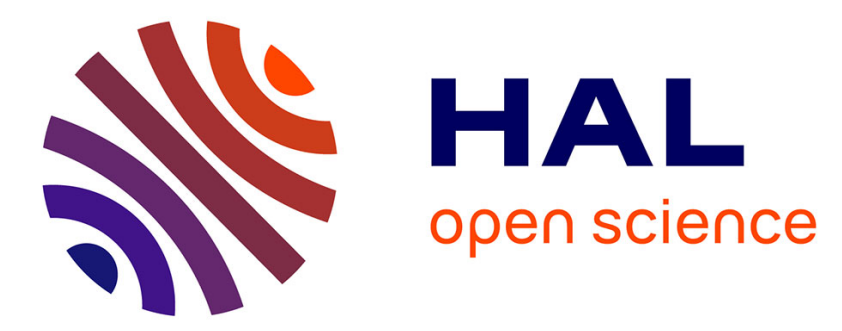

\title{
Survival of in Seawater and Retention of Virulence of Its Starved Cells
}

Ben Kahla-Nakbi Amel, Besbes Amine, Chaieb Kamel, Rouabhia Mahmoud, Bakhrouf Amina

\section{- To cite this version:}

Ben Kahla-Nakbi Amel, Besbes Amine, Chaieb Kamel, Rouabhia Mahmoud, Bakhrouf Amina. Survival of in Seawater and Retention of Virulence of Its Starved Cells. Marine Environmental Research, 2007, 64 (4), pp.469. 10.1016/j.marenvres.2007.04.002 . hal-00562978

\section{HAL Id: hal-00562978 \\ https://hal.science/hal-00562978}

Submitted on 4 Feb 2011

HAL is a multi-disciplinary open access archive for the deposit and dissemination of scientific research documents, whether they are published or not. The documents may come from teaching and research institutions in France or abroad, or from public or private research centers.
L'archive ouverte pluridisciplinaire HAL, est destinée au dépôt et à la diffusion de documents scientifiques de niveau recherche, publiés ou non, émanant des établissements d'enseignement et de recherche français ou étrangers, des laboratoires publics ou privés. 


\section{Accepted Manuscript}

Survival of Vibrio alginolyticus in Seawater and Retention of Virulence of Its Starved Cells

Ben Kahla-Nakbi Amel, Besbes Amine, Chaieb Kamel, Rouabhia Mahmoud, Bakhrouf Amina

PII:

S0141-1136(07)00057-8

DOI:

10.1016/j.marenvres.2007.04.002

Reference:

MERE 3116

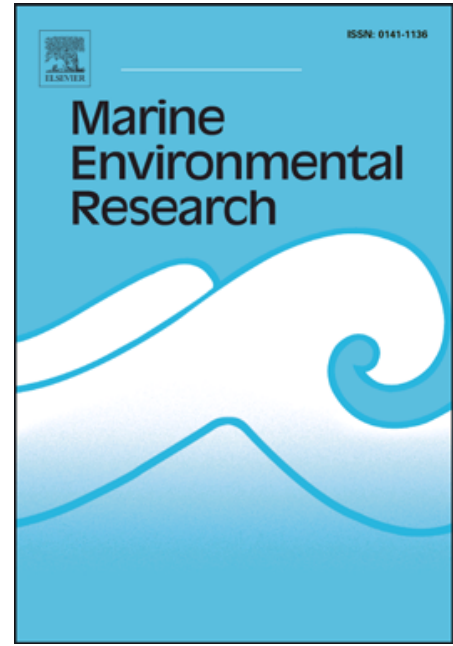

To appear in:

Marine Environmental Research

Received Date:

21 May 2006

Revised Date:

24 March 2007

Accepted Date:

2 April 2007

Please cite this article as: Amel, B.K-N., Amine, B., Kamel, C., Mahmoud, R., Amina, B., Survival of Vibrio alginolyticus in Seawater and Retention of Virulence of Its Starved Cells, Marine Environmental Research (2007), doi: 10.1016/j.marenvres.2007.04.002

This is a PDF file of an unedited manuscript that has been accepted for publication. As a service to our customers we are providing this early version of the manuscript. The manuscript will undergo copyediting, typesetting, and review of the resulting proof before it is published in its final form. Please note that during the production process errors may be discovered which could affect the content, and all legal disclaimers that apply to the journal pertain. 
Survival of Vibrio alginolyticus in Seawater and Retention of Virulence of Its Starved Cells

\author{
BEN KAHLA-NAKBi Amel", BeSbeS Amine ${ }^{1}$, CHAIEB Kamel, ROUABHIA \\ Mahmoud $^{2}$, BAKHROUF Amina ${ }^{1}$
}

1-Laboratoire d'Analyse et de Contrôle des Polluants Chimiques et Microbiologiques de l'Environnement. Faculté de Pharmacie de Monastir rue Avicenne, 5000 Monastir. TUNISIA

2- Groupe de Recherche en Écologie Buccale, Faculté de Médecine Dentaire, Université Laval, Québec, QC, CANADA.

\begin{abstract}
The aim of this study was to evaluate the survival responses of four strains of Vibrio alginolyticus in seawater under starvation conditions. We used microcosms containing sterilised seawater and incubated at ambient temperature $\left(22-25^{\circ} \mathrm{C}\right)$. Vibrio alginolyticus maintained its culturability for at least nine months. Long-term-starved cells showed an absence or a decrease in their enzymatic activities. Resuscitation assays of viable but nonculturable (VBNC) cells were conducted and the recovery of these cells was achieved after the addition of nutrients. Amplified 16S ribosomal DNA (rDNA) restriction analysis (ARDRA) was used to confirm that the same strain of Vibrio alginolyticus persisted in all microcosms during a long period of time. Starved cells maintained their infectivity for gilt head sea bream (Sparus aurata) and sea bass (Dicentrachus labrax) as determined by intraperitoneal challenges.
\end{abstract}

Key words: Vibrio alginolyticus, survival, seawater, VBNC, ARDRA, virulence. 
* Correspondance author: Amel Ben kahla-Nakbi. Laboratoire d'Analyse et de Contrôle des Polluants Chimiques et Microbiologiques de l'Environnement. Faculté de Pharmacie, Rue Avicenne, 5000 Monastir. TUNISIE.

E-mail: nakbi_amel@yahoo.fr

\section{Introduction}

Lack of nutrients in natural ecosystems are often the limiting factor for microbial populations. Under unfavourable environmental conditions, Vibrio spp., like other bacterial species including Aeromonas, Campylobacter, Salmonella and Shigella, have a survival strategy, entering a viable but not culturable (VBNC) state (Biosca, Amaro, MarcoNoales, \& Oliver 1996; Jiang \& Chai 1996). In this state, the cells remain viable but no longer grow in, or develop colonies on, the non-selective media normally employed for their culture (Jiang \& Chai 1996).

In the last decade, it has been frequently reported that under appropriate conditions, these microorganisms are nevertheless able to recover from this dormant state, becoming metabolically active and fully culturable (Nilsson, Oliver, \& Kjelleberg, 1991; Whitesides \& Oliver, 1997). However, it has been proposed that the VBNC state is an adaptative strategy of microorganisms against stress from which cells may be able to recover once optimal conditions are restored (Huq \& Colwell 1995; Nybroe, 1995; Oliver 1995). This problem is even more complex for bacterial pathogens, since these microorganisms in VBNC state may remain pathogenic (Rahman, Shahamat, Kirchman, Russek-Cohen, \& Colwell, 1994).

Vibrio alginolyticus is a species with a broad geographical distribution in marine and estuarine waters; especially in bathing areas (Barbieri et al., 1999; Baffone, Pianetti, Bruscolini, Barbieri, \& Citterio, 2000). It has been associated with several diseases of marine animals, including fish and shellfish (Balebona, Andreu, Bordas, Zorrilla, Moriñigo, Borrego, 
1998; Gomez-Leon et al., 2005; Ben kahla-Nakbi et al., 2006). The route of infection and transmission of this species remains to be investigated. One method of transmission might be through seawater, either as bacterioplankton or on the surface of particles. It is also not known whether this bacterium is endemic to the marine environment and whether it behaves as an opportunistic fish pathogen.

The aim of the present work was to investigate the effect of marine stress on the behaviour of $V$. alginolyticus incubated in seawater microcosms. In addition, to assess the environmental health hazard posed by this bacterium, we studied the ability of long-term-starved cells to express virulent exoenzymes and infect cultured fish.

\section{Materials and Methods}

\subsection{Bacterial Strains and Growth Conditions}

Four strains of $V$. alginolyticus isolates representative of different epizootic events were used in this study. All were recovered from the internal organs of diseased gilt head sea bream (VD4, VD5) and sea bass (VL12, VL13) in a Tunisian aquaculture centre. Stock cultures were frozen at $-80^{\circ} \mathrm{C}$ with $20 \%$ (vol/vol) glycerol. Bacteria were routinely cultured on tryptic soy agar (TSA-1) or in tryptic soy broth (TSB-1) supplemented with $1 \% \mathrm{NaCl}$ (Difco) at $22^{\circ} \mathrm{C}$.

Bacterial strains were subjected to standard morphological, physiological and biochemical plate and tube tests using the procedures described in Bergey's Manual of Systematic Bacteriology (Krieg and Holt, 1984). Gram staining, the oxidase test, morphology, motility, susceptibility to the vibriostatic compound $\mathrm{O} / 129$ and growth on thiosulfate citrate bile sucrose agar were the main assays employed to identify the organisms. A commercial miniaturized API 2OE Kit (Bio-Mérieux) was also used.

\subsection{Survival Assay}


A 24 -hour culture was centrifuged at $12000 \mathrm{~g}, 4^{\circ} \mathrm{C}$ for $15 \mathrm{~min}$. The pellet was washed three times with a saline solution. Then the cells were inoculated into Erlenmeyer flasks containing $500 \mathrm{ml}$ of sterile seawater from the Tunisian coast of Monastir (salinity 4\%, $\mathrm{pH}=8$ ) until a concentration varying between $10^{6}$ and $10^{8}$ colony-forming units (CFU) per ml was reached. All microcosms were incubated in a static state at ambient temperature $\left(22-25^{\circ} \mathrm{C}\right)$.

\subsection{Enumeration Techniques}

Microcosms were sampled daily during the first week, weekly during the first three months, and then once a month. Time zero (inoculation time) and subsequent samples were taken for plate counts. Plate counts of culturable cells were determined by the drop plate method (Hoben \& Somasegaran 1982), using marine agar (MA) and selective medium ThiosulfateCitrate-Bile Salts-Sucrose (TCBS). The plates were incubated at room temperature, and the number of colonies was counted after 24 and $48 \mathrm{~h}$ ).

\subsection{Statistical Analysis}

Two microcosms per strain were constructed. Three samples per microcosm were taken for plate counts using marine agar (MA) and selective medium (TCBS). Culturable-cell counts from the experiments were processed for variance analysis using the procedure of the general lineal model with repeated measures available in the SPSS package.

\subsection{Resuscitation of VBNC Cells}

When cells were considered to be non-culturable $(<1 \mathrm{CFU} / \mathrm{ml})$, reversion to a culturable state was attempted by removing $5 \mathrm{ml}$ of seawater from each microcosm at ambient temperature and placing them in a $10 \mathrm{ml}$ Luria -Bertani (LB) broth. After incubation at $28^{\circ} \mathrm{C}$, culturability was assayed in marine agar.

\subsection{Biochemical Activities and Exoenzyme Expression}


Biochemical activities of initial cells of $V$. alginolyticus and long-term-starved cells incubated in seawater was performed on API 20E (Bio-Mérieux). The presence of several exoenzymes was determined using the API Zym System (Bio-Mérieux) composed of 19 enzymatic substrates. The activities of various other enzymes were determined following inoculation of cultures onto TSA- 1 to which the following substrates had been added: $0,2 \%$ [wt/vol] strach for amylase, $1 \%[\mathrm{wt} / \mathrm{vol}]$ skim milk for caseinase, $1 \%[\mathrm{wt} / \mathrm{vol}]$ gelatin for gelatinase, $1 \%$ Tween 80 for lipase, $5 \%$ [vol/vol]) egg yolk for phospholipase (lecithinase) and 5\% [vol/vol]) sheep red blood cells for haemolysin.

\subsection{ARDRA (Amplified Ribosomal DNA Restriction Analysis)}

Amplified 16S ribosomal DNA (rDNA) restriction analysis (ARDRA), using enzyme HaeIII was applied to starved cells of $V$. alginolyticus (cells incubated in seawater microcosms) and initial cells to compare their profiles.

Samples to be used for ARDRA analysis were obtained by centrifuging $5 \mathrm{ml}$ of the starvation microcosm at 16,000 $\mathrm{g}$ for $5 \mathrm{~min}$. Cells were washed and resuspended in $10 \mathrm{ml}$ of LB broth. After 24 hour incubation at $28^{\circ} \mathrm{C}$, chromosomal DNA was extracted using a Wizard Genomic Purification Kit (Promega). The amplified 16S rRNA gene was obtained from each isola te and reference strain by PCR with the universal primers F (5' AAT CAC TAC CGG AAA CAG CG 3') and R (5' TGC ACT CAA TGA GGG AAT CA 3'), targeted to universally conserved regions and permit the amplification of an approximate 1,500-bp fragment. PCR amplification was performed by $2 \mu 1$ of bacterial DNA, $0.25 \mu 1$ of Go Taq DNA polymerase (Promega), $1.25 \mu \mathrm{l}$ of Green Go Taq tampon; $1,5 \mu 1$ of $\mathrm{MgCl}_{2}(50 \mathrm{mM}), 0.2 \mathrm{mmol}$ of each dATP, dCTP, dGTP and dTTP and 50 pmol of each primer. The PCR program consists of 30 cycles having the following parameters: denaturation at $94{ }^{\circ} \mathrm{C}$ for $1 \mathrm{~min}$, hybridization at 55 ${ }^{\circ} \mathrm{C}$ for 1 min and annealing at $72{ }^{\circ} \mathrm{C}$ for 1 min and 30s. Amplified DNA was used as such for restriction with the enzyme HaeIII (1U) at $37^{\circ} \mathrm{C}$ for $3 \mathrm{~h} 30$. 
PCR products were mu in $2 \%$ agarose gels electrophoresis submerged in $1 \mathrm{X}$ Tris -borateEDTA buffer (TBE) under 90 volts.

DNA in the gel was visualized by exposure to UV light and photographed using a Gel Doc XR apparatus (Bio-rad, USA). The size of DNA fragments was estimated using a $100 \mathrm{bp}$ DNA ladder (Promega).

\subsection{Virulence for Fish}

The virulence potential of starved cells was tested in tanks containing 50 litres of seawater maintained at $25^{\circ} \mathrm{C}$ with sea bass $(10 \mathrm{~g}$ body weight) for VL13 and gilt head sea bream (10 g body weight) for VD5. Groups of ten fish were injected intraperitoneally with $0.1 \mathrm{ml}$ of bacterial suspension of esuscitated cells $\left(10^{4}-10^{6} \mathrm{CFU} / \mathrm{ml}\right)$. Mortality was recorded daily during a 10-day period and was considered only if the bacterium was reisolated as a pure culture from internal organs. Fish inoculated with phosphate buffer saline (PBS) and exponential phase growth cells were also included as controls. Percent mortality at the end of the experiments was recorded.

\section{Results}

\section{1. Survival Curves during Starvation}

The survival of $V$. alginolyticus in sterilised seawater at ambient temperature under starvation was investigated. Cultivability on MA and selective medium TCBS was studied. Our results showed that cells remained culturable for prolonged periods of time in all microcosms (Fig 1, 2). At room temperature $\left(22-25^{\circ} \mathrm{C}\right)$ no difference showed in the culturability for VD4 and VD5. The survival curves fell into three stages. At the beginning of starvation, cells lost culturability rapidly within two weeks. This was followed by a slow decline in culturability and then a drop of plate counts to less than 1 cell per $\mathrm{ml}$ after nine months for VD4 and VD5, seven months for VL12 and six months for VL13. 
The selective medium, TCBS, was compared with the non-selective medium, MA, for enumeration of culturable cells. The difference between TCBS and MA counts of strains VL12 and VL13 was about $1 \log$ at the initial time point, but thereafter, the difference became greater. However, we did not observe any difference between TCBS and MA counts of strains VD4 and VD5. Theoretically, the plate count difference between non-selective and selective media represents the number of injured cells that have been exposed to a sublethal physical or chemical environment, such as heat, refrigeration, freezing, and so on (Jiang \& Chai 1996). For the VD4 and VD5 strains, it appeared that starvation did not cause cell injury, since the difference between MA and TCBS counts was constant regardless of how long the cells were starved (Fig 1). In contrast, more cells were injured for the strains VL12 and VL13, as evidenced by an increasing difference between MA and TCBS plate counts (Fig 2).

\subsection{Enzymatic Changes of V. alginolyticus during Starvation}

The results of API 20E tests showed no modification in the biochemical profile of all $V$. alginolyticus strains incubated in seawater microcosms after a long period of starvation. Thus, on API ZYM galleries, and after six months of starvation, VD4 and VD5 lost many of their enzymatic activities. VD4 express only the Naphtol-AS-BI-phosphohydrolase and VD5 express the Naphtol-AS-BI-phosphohydrolase and Leucine arylamidase (Fig 3 A). In prepared mediums, VD4 lost all its virulence factors and for VD5, only caseinase, DNASE and lipase activities were detected (Table 1). However, strains isolated from sea bass (VL12 and VL13) showed a remarkable decrease in their enzymatic production level (Fig 3 B), except for the phosphatase alkaline and Naphtol-AS-BI-phosphohydrolase produced by VL13. These findings could be explained by the preparation of cells to enter into the VBNC state characterized by low metabolic rate, reduction in size, morphological changes or synthesis of specific proteins. This adaptation strategy developed by bacteria in aquatic environments allows them to survive during a long period of time. 


\subsection{Results of ARDRA}

V. alginolyticus cells starved for as long as one year were able to regain the ability to be amplified with the addition of nutrients to starved cells from microcosms. VBNC cells were resuscitated by adding seawater microcosms to $\mathrm{LB}$ broth and incubation at $28^{\circ} \mathrm{C}$. DNA was easily extracted and PCR amplification did not fail with the primers selected, giving a unique pattern at 1500 bp (Fig 4, lanes 12, 13, 14, 15, 16, 17, 18, 19). ARDRA showed the same profile for the strains of $V$. alginolyticus isolated from gilt head sea bream (VD4 and VD5) and sea bass (VL12 and VL13). Profiles of initial cells were similar to the profile of starved cells (incubated 1year) (Fig 5, lanes 3, 4, 5, 6, 7, 8, 9, 10). These data confirm that this was the same strain that resists in all microcosms during a long period of time.

\subsection{Virulence Assay}

This test was assayed for the strain VL13 and VD5. Cells from microcosms were able to infect cultured fish, gilt head sea bream (Sparus aurata) and sea bass (Dicentrarchus labrax) by i.p. injection, even after one year of starvation (Table 2). Starved cells presented a degree of virulence similar to that of non-starved cells used as controls. The retention of virulence under conditions simulating those found in the aquatic environment is additional evidence supporting the hypothesis that water is one of the natural reservoirs of this pathogen.

\section{Discussion}

Under adverse conditions, Vibrio species can survive and adapt for a long period of time, and like many other microorganisms, they can enter a viable but non-culturable state (Morita, 1993; Oliver, 1995). This state was employed mainly by gram-negative bacteria and has been proposed as a strategy for survival by bacteria in the natural environment (Ben kahla-Nakbi, Besbes, Bakhrouf, 2006; Baffone et al., 2003; Gupte, De Rezende, \& Joseph, 2003; 
Whitesides \& Oliver, 1997). Temperature (Oliver, Nilsson \& Kjelleberg, 1991), as well as nutrient limitation (Fouz, Toranzo, MarcoNoales, \& Amaro, 1998), levels of osmolarity, humidity (Heidelberg et al., 1997), and aeration (Rollins \& Colwell 1986), have been found to be important factors that contribute to the induction of the VBNC state.However, the stresses of nutrient deprivation and low temperature have been shown to be the main causes of the induction of VNC stages in some pathogenic bacteria (Oliver, 1993; Colwell \& Huq, 1994). This study showed the development of the VBNC state in $V$. alginolyticus in nutrient-limiting microcosms for prolonged periods of time. It was possible to resuscitate the non-culturable organisms by nutrient addition at $28^{\circ} \mathrm{C}$. Many reports suggested that the culturable population which appears is a result of regrowth of one or more culturable cells in the population that had not been detected when the population was assayed (Weichart, Oliver, \& Kjelleberg, 1992; Jiang \& Chai, 1996). Ravel et al. (1995) reported that recovery of VNC cells of $V$. cholerae from starvation at $4{ }^{\circ} \mathrm{C}$ in nutrient-limited artificial seawater after a temperature upshift to $30^{\circ} \mathrm{C}$ was due to regrowth of surviving cells but not resuscitation of all VNC cells. However, Oliver et al. (1995) demonstrated that the rapid development of culturability represents a true resuscitation of the VBNC population to the actively metabolizing, culturable state and is not a result of growth of a few residual cells present in membrane diffusion chambers. Whitesides and Oliver (1997) noted that, regardless of the duration for which the VBNC cells were present in a high level of nutrient, the number of culturable cells ultimately present did not exceed that of control cells resuscitated at room temperature, but without being exposed to the added nutrient. They supposed that if culturable cells had been present among the VBNC cells, a population approaching $10^{8} \mathrm{CFU} / \mathrm{ml}$ or greater would have been expected following these conditions of incubation. This observation argues that no culturable cells were present in the microcosms. And to further examine whether regrowth of undetected culturable cells, as opposed to true resuscitation of VBNC cells, might account for the appearance of the large 
culturable populations routinely observed following a temperature upshift in nutrient-free artificial seawater (ASW), the same group made different dilutions of ASW, and they concluded that resuscitation occurred in each dilution, with final culturable populations reaching levels reflecting the dilution applied.

Recently, Kong et al., 2004 reported that entry of V. vulnificus into the VBNC state is due largely to the loss of catalase activity in these cold-incubated cells, and that resuscitation is likely due to the production of catalase in $\mathrm{H}_{2} \mathrm{O}_{2}$-free diluents (e.g. ASW) at permissive (e.g. room) temperatures.

VBNC cells do indeed leave this dormant state upon removal/reversal of the inducing factor; in our case, the absence of nutrients and osmotic shock during nine months were the inducing factors of entrance into the VBNC state. Moreover, the resuscitation phenomenon $x$ curred once these adverse conditions were reversed (addition of nutrients).

Various viability assays have been successfully employed to detect the presence of VBNC cells, such as direct viable count (Kogure, Simidu \& Taga, 1979); florescence microscopy using various stains, e.g., cyanoditolyl tetrazolium chloride (CTC) (Rodriguez, Phipps, Ishiguru \& Ridgway,1992); and more recently molecular genetic methods (Warner, \& Oliver, 1998; Lázaro, Cárcamo, Audicana, Perales \& Fernández-Astorga, 1999). However, the eventual proof of vitality is through resuscitation of the cells and confirmation that the recovered cells are indeed identical to the starting cells (Gupte, De Rezende, \& Joseph, 2003). In this study, ARDRA was used to confirm that the same strain of Vibrio alginolyticus resists in all microcosms during a long period of time and transforms into a VBNC state (Fig 5). Yaron \& Matthews (2002) reported a variety of genes, including those required for 16S rRNA synthesis, continued to be expressed in nonculturable cells of E. coli O157:H7.

However, the question posed by many authors was "Can starved cells retain their virulence factors and still remain pathogenic for humans and animals?" 
Long-starved cells of $V$. vulnificus biotype 2 maintained their ability to infect eels and humans. culturable cells from saline microcosms were able to infect eels and mice, even after two years of starvation (Macro-Noals, Biosca, \& Amaro, 1999). Stable virulence of other bacterial species in the VBNC state was reported previously. VBNC Escherichia coli and V. cholerae cells, for example, were isolated from rabbit ileal loops in which enterotoxigenicity was exhibited (Colwell et al. 1985; Grimes \& Colwell, 1986).

Vibrio spp. can be transmitted through seawater. They are attached to surfaces or surviving in sediments; they can reinfect fish farms seasonally when conditions are favourable (Hoff, 1989).

Our experiences showed that, on the one hand, starved cells of $V$. alginolyticus can retain their virulence enzymes (VD5 and VL13) and can reinfect cultured fish even after a long period of starvation. On the other hand, starved cells of VD4 and VL12 appeared to lose all or an important part of their exoenzymes (Table 1). The pathogenicity and conservation of virulence factors seems to be a strain-specific expression. The high diversity of strains belonging to the same species may explain the strain-specific expression of virulence factors and, consequently, the different data obtained from various geographic areas (Baffone, Vittoria, Campana, Citterio, Casaroli, Pierfelici, 2005). Moreover, the loss of virulence enzymes of the two studied strains (VD4 and VL12) might be virtual, and cells could be resuscitated after passage in the animal. Baffone et al., (2003) demonstrated that VBNC forms of two environmental strains $V$. alginolyticus and $V$. paraheamolyticus obtained by culturing bacteria in seawater microcosms and incubating at $5{ }^{\circ} \mathrm{C}$ can be resuscitated and retain their virulence properties after two consecutive passages of the strains in the rat ileal loop model.

\section{Conclusion}

In summary, our results suggest that $V$. alginolyticus has developed strategies that allow it to survive in seawater in the absence of nutrients and outside its natural host. Under these 
conditions, this bacterium maintains its potential to infect fish. Our results are in accordance with those obtained in similar studies performed with other species of Vibrio, autochthonous members of aquatic ecosystems. This means that $V$. alginolyticus is an opportunistic pathogen whose main reservoir is probably the aquatic environment where it can survive at different rates, depending on temperature. From these environments, the bacterium could infect susceptible fish, multiply in them following the development of vibriosis and be liberated in large numbers into the environment.

\section{Acknowledgment}

We would like to thank Pr. JEMMALI Mongi director of the club "Young and Sciences" of Monastir for providing the local and aquaria for infection experiments.

\section{References}

Baffone, W., Citterio, B., Vittoria, E., Casaroli, A., Campana, R., Falzano, L., \& Donelli, G. (2003). Retention of virulence in viable but non-culturable halophilic Vibrio spp. International Journal of Food Microbiology, 89, 31-39.

Baffone, W., Pianetti, A., Bruscolini, F., Barbieri, E., \& Citterio, B. (2000). Occurrence and expression of virulence-related properties of Vibrio species isolated from widely consumed seafood products. International Journal of Food Microbiology, 54, 9-18.

Baffone, W., Vittoria, E., Campana, R., Citterio, B., Casaroli, A., \& Pierfelici, L. (2005). Occurrence and expression of virulence-related properties by environmental halophilic Vibrio spp. in in vitro and in vivo systems. Food Control, 16, 451-457

Balebona, M.C., Andreu, M.J., Bordas, M.A., Zorrilla, I., Moriñigo, M.A., \& Borrego, J.J. (1998). Pathogenicity of Vibrio alginolyticus from cultured gilt-head sea bream (Sparus aurata, L.). Applied and Environmental Microbiolog y, 64, 4269-4275. 
Barbieri, E., Falzano, L., Fiorentini, C., Pianetti, A., Baffone, W., Fabbri, A., Matarrese, P., Casiere, A., Katouli, M., Kühni, I., Möllby, R., Bruscolini, F., \& Donelli, G. (1999). Occurrence, diversity, and pathogenicity of halophilic Vibrio spp. and non-01 Vibrio cholerae from estuarine waters along the Italian Adriatic coast. Applied and Environmental Microbiolog y, 65, 2748- 2753.

Ben kahla-Nakbi, A., Chaieb, K., Besbes, A., Zmantar, T., \& Bakhrouf, A. (2006).Virulence and Enterobacterial Repetitive Intergenic Consensus PCR of Vibrio alginolyticus strains isolated from Tunisian cultured gilthead sea bream and sea bass outbreaks. Veterinary Microbiology, 117, 321-327.

Ben kahla-Nakbi, A., Besbes, A., \& Bakhrouf, A. (2006). Survival of Vibrio fluvialis in Sea Water under Starvation Conditions. Microbiological Research. (in press).

Biosca, E.G, Amaro, C., Marco-Noales, E., \& Oliver, J.D. (1996). Effect of low temperature on starvation-survival of the eel pathogen Vibrio vulnificus biotype 2. Applied and Environmental Microbiology, 62, 450-455

Colwell, R. R, \& Huq, A. (1994). Vibrios in the environment: viable but nonculturable Vibrio cholerae, p. 117-133. In I. K. Wachsmuth, P. A. Blake,and Ø. Olsvik (ed.), Vibrio cholerae and cholera: molecular to global perspectives. ASM Press, Washington, D.C.

Fouz, B., Toranzo, A.E., Marco-Noales, E., \& Amaro, C. (1998). Survival of fish-virulent strains of Photobacterium damselae subsp. damselae in seawater under starvation conditions. FEMS Microbiology Letters, 168, 181-186.

Gupte, A. R., de Rezende, C. L. E., \& Joseph, S. W. (2003). Induction and Resuscitation of Viable but Nonculturable Salmonella enterica Serovar Typhimurium DT104. Applied and Environmental Microbiolog y, 69, 6669-6675. 
Heidelberg, J.F., Shahamat, M., Levin, M., Rahman, I., Stelma, G., Grim, C., \& Colwell R. R. (1997). Effect of aerosolization on culturability and viability of gram-negative bacteria. Applied and Environmental Microbiolog y, 63, 3585-3588.

Hoben, H.J., \& Somasegaran, P. (1982). Comparison of the pour, spread, and drop plate methods for enumeration of Rhizobium spp. in inoculants made from presterilized peat. Applied and Environmental Microbiolog y, 44, 1246-1247.

Hoff, K.A. (1989). Survival of Vibrio anguillarum and Vibrio salmonicida at Different Salinities. Applied and Environmental Microbiology, 55, 1775-1786.

Holt, J.E, Krieg, Smeath, N.R., P.H.A., Staley, J.T., \& Williams, S.T. (1994). Genus Vibrio. Bergey's Manual of déterminative bacteriology, $9^{\text {th }}$ ed. Pages: 192-194.

Huq, A., \& Colwell, R.R. (1995). A microbiological paradox: viable but nonculturable bacteria with special reference to Vibrio cholerae. Journal of Food Protection, 59, 96101.

Jiang, X., \& Chai, T.J. (1996). Survival of Vibrio parahaemolyticus at low temperatures under starvation conditions and subsequent resuscitation of viable, nonculturable cells. Applied and Environmental Microbiology, 62, 1300-1305.

Kogure, K., Simidu, U., \& Taga, N. (1979). A tentative direct microscopic method for counting living bacteria. Canadian Journal of Microbiology, 25, 415-420.

Kong, I.S., Bates, T.C., Hülsmann, A., Hassan, H., Smith, B. E., \& Oliver, J. D. (2004). Role of catalase and oxyR in the viable but nonculturable state of Vibrio vulnificus. FEMS Microbiology Ecology 50,133-142.

Lázaro, B., Cárcamo, J., Audicana, A., Perales, I., \& Fernández-Astorga, A. (1999). V iability and DNA maintenance in nonculturable spiral Campylobacter jejuni cells after long-term exposure to low temperatures. Applied and Environmental Microbiology, 65, 4677-4681. 
Macro -Noals, E., Biosca, E.G., \& Amaro, C. (1999). Effects of salinities and temperature on long term survival of the eel pathogen Vibrio vulnificus biotyppe 2 (seovar E). Applied and Environmental Microbiology, 65, 1117-1126.

Morita, R.Y. (1993). Bioavailability of energy and the starvation state, p. 1-23. In S. Kjelleberg (ed.), Starvation in bacteria. Plenum Press, New York.

Nilsson, L., Oliver, J.D., \& Kjelleberg, S. (1991). Resuscitation of Vibrio vulnificus from the viable but nonculturable state. J. Bacteriol. 173, 5054-5059.

Nybroe, O. (1995). Assessment of metabolic activity of single bacterial cells - new developments in microcolony and dehydrogenase assays. FEMS Microbiology Ecology, $17,77-84$.

Oliver, J. D. (1993). Formation of viable but nonculturable cells, p. 239-272. In S. Kjelle berg (ed.), Starvation in bacteria. Plenum Press, New York.

Oliver, J. D., Nilsson, L., \& Kjelleberg, S. (1991). Formation of nonculturable Vibrio vulnificus cells and its relationship to the starvation state. Applied and Environmental Microbiology, 57, 2640-2644.

Oliver, J.D. (1995). The viable but nonculturable state in the human pathogen Vibrio vulnificus. FEMS Microbiology Letters, 133, 203-208.

Oliver, J.D., Hite, F., McDougald, D., Andon, N.L., \& Simpson, L.M. (1995). Entry into, and resuscitation from, the viable but nonculturable state by Vibrio vulnificus in an estuarine environment. Applied and Environmental Microbiology, 61, 2624-2630.

Rahman, I., Shahamat, M., Kirchman, P.A., Russek-Cohen, E., \& Colwell, R.R. (1994). Methionine uptake and cytopa thogenicity of viable but nonculturable Shigella dysenteriae type 1. Applied and Environmental Microbiolog y, 60, 3573- 3578.

Ravel, J., Hill, R. T., Knight, I. T., Dubois, C. R., \& Colwell, R. R. (1993).Recovery of Vibrio cholerae from the viable but non-culturable state, abstr.Q-6, p. 347. Abstracts of the 93rd 
General Meeting of the American Society for Microbiology 1993. American Society for Microbiology, Washington, D.C.

Rodriguez, G.G., Phipps, D., Ishiguru, K., \& Ridgway, H. F. (1992). Use of a fluorescent redox probe for direct visualization of actively respiring bacteria. Applied and Environmental Microbiolog y, 58, 1801-1808.

Rollins, D.M., \& Colwell. R. R. (1986). Viable but nonculturable stage of Campylobacter jejuni and its role in survival in the natural aquatic environment. Applied and Environmental Microbiology, 52, 531-538.

Warner, J. M., \& Oliver, J. D. (1998). Randomly amplified polymorphic DNA analysis of starved and viable but nonculturable Vibrio vulnificus cells. Applied and Environmental Microbiology, 64, 3025-3028.

Weichart, D., Oliver, J. D., \& Kjelleberg, S. (1992). Low temperature induced nonculturability and killing of Vibrio vulnificus. FEMS Microbiology Letters, 100, 205210.

Whitesides, M.D., \& Oliver, J.D. (1997). Resuscitation of Vibrio vulnificus from the viable but nonculturable state. Applied and Environmental Microbiology, 63, 1002- 1005.

Yaron, S., \& Matthews, K. (2002). A reverse transcriptase polymerase chain reaction assay for detection of viable Escherichia coli O157:H7: investigation of specific target genes. Journal of Applied Microbiology, 92, 633-640. 
Table 1. Exoenzymes expression (prepared mediums) by $V$. alginolyticus strains before and afterincubation in sea water microcosms.

Exoenzymes

Exoenzymes expression by strain:

\begin{tabular}{lcccccccc} 
& VD4 $^{\mathrm{i}}$ & VD4 & VD5 $^{\mathrm{i}}$ & VD5 $^{\mathrm{s}}$ & $\mathrm{VL12}^{\mathrm{i}}$ & VL12 $^{\mathrm{s}}$ & VL13 $^{\mathrm{i}}$ & VL13 $^{\mathrm{s}}$ \\
\hline Amylase & + & - & + & - & + & - & + & + \\
Caseinase & + & - & + & + & - & - & + & + \\
DNASE & + & - & + & + & - & - & + & + \\
Gelatinase & + & - & + & - & + & - & + & + \\
Lipase & + & - & + & + & + & + & + & + \\
Phospholipase & + & - & + & - & + & - & - & - \\
Hemolysin & - & - & $+(\boldsymbol{B})$ & $+(\mathbf{a})$ & - & - & $+(\mathbf{B})$ & - \\
\end{tabular}

i: initial cells (Strain before incubation in sea water microcosms), s: starved strain (after 6 months of incubation in sea water microcosms), (B): complete haemolysis, (a): incomplete haemolysis. 
Table 2. Mortality of fish inoculated with starved cells and of controls of $V$. alginolyticus during 10 days

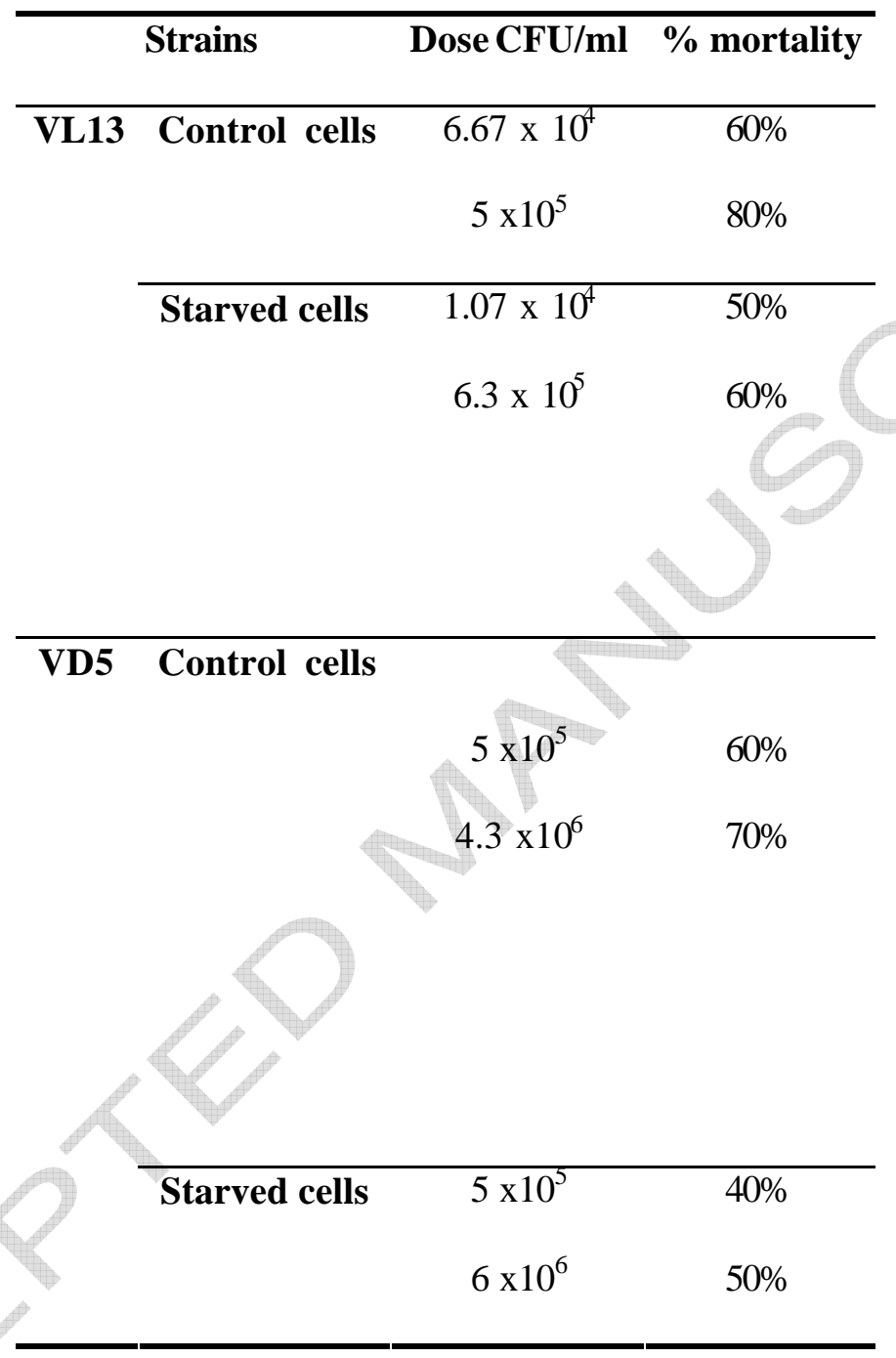




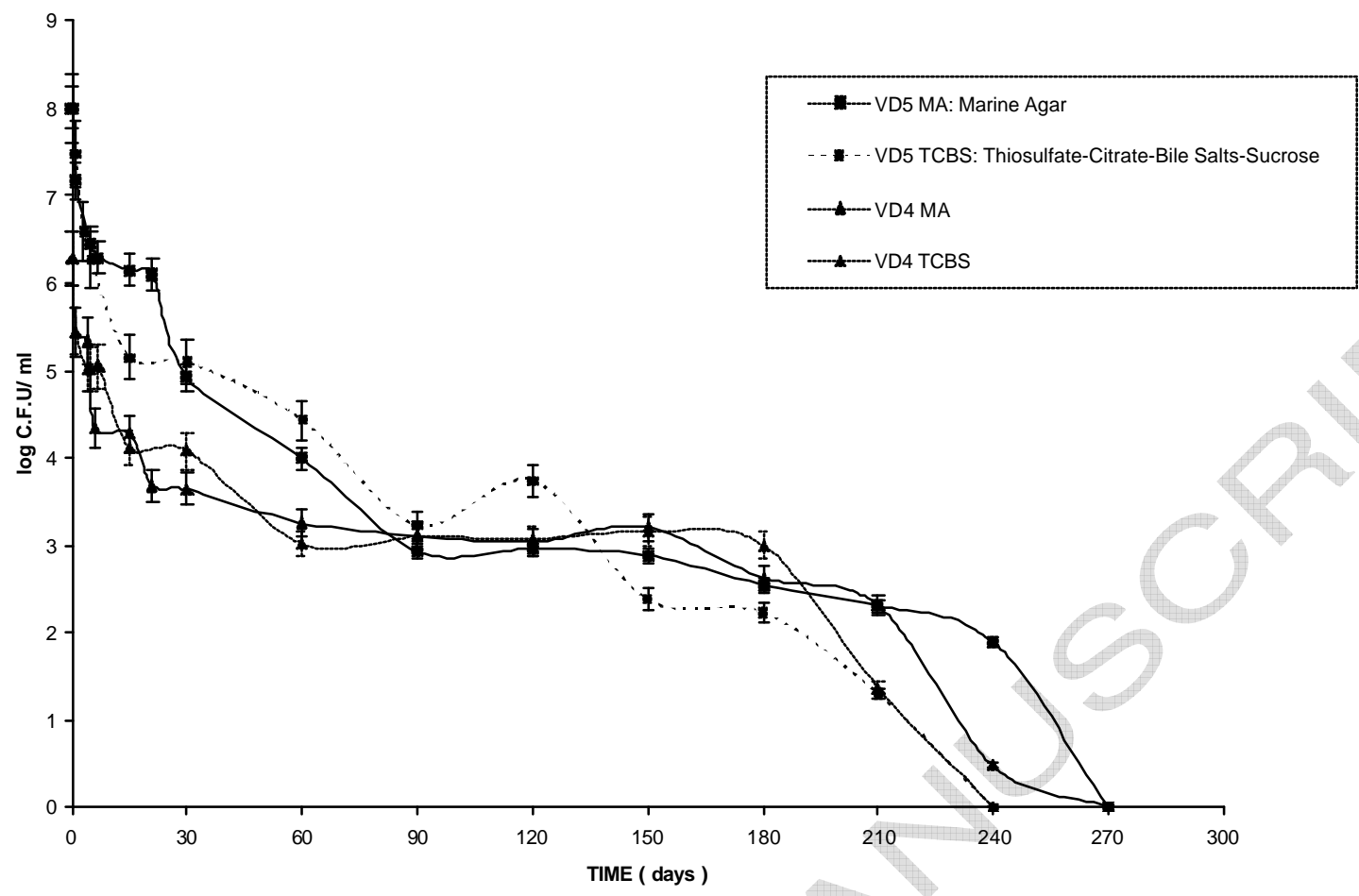

Fig 1. Survival curves of strains VD5, VD4 at ambient temperature solid line: Marine Agar (MA), dashed line: Thiosulfate-Citrate-Bile Salts-Sucrose (TCBS)

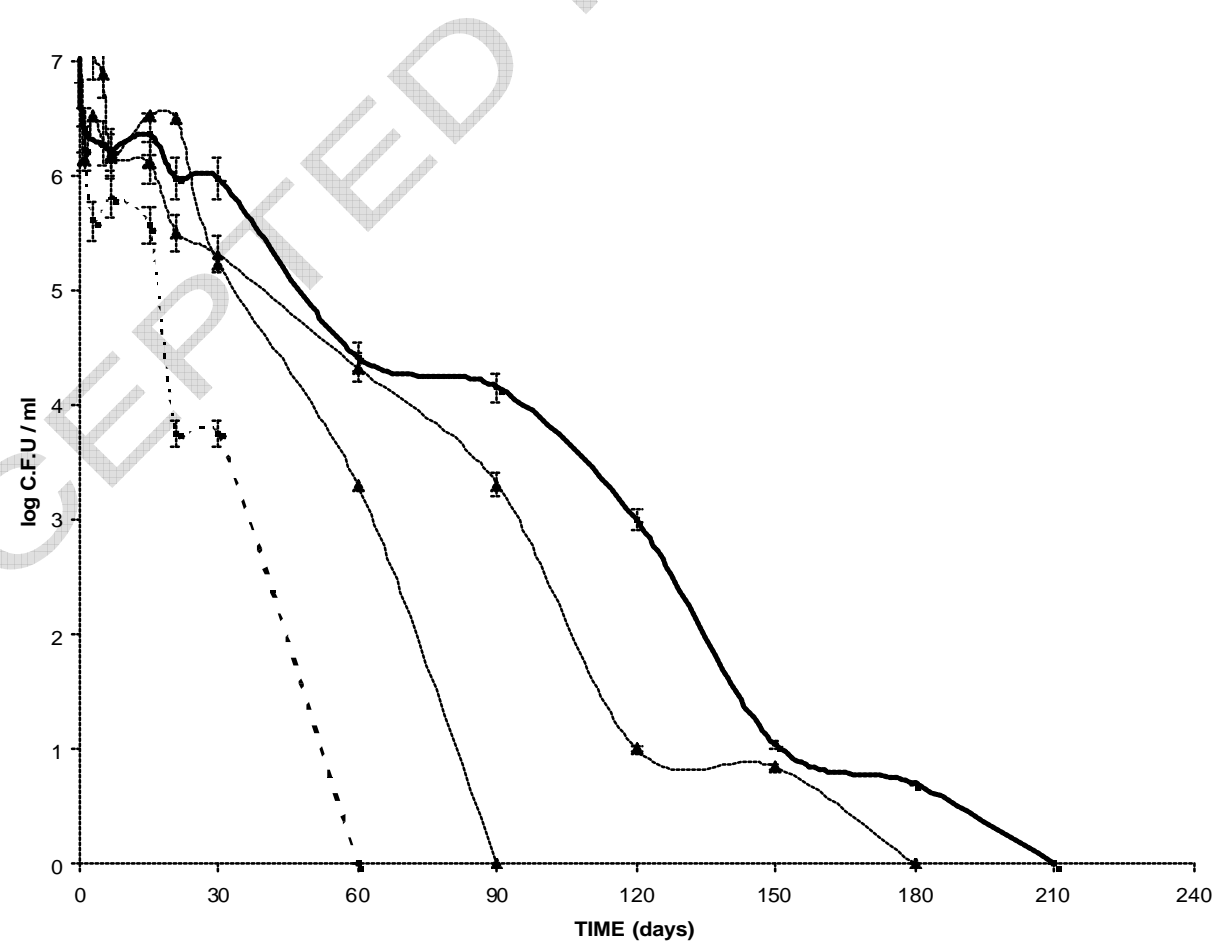

Fig 2. Survival curves of strains VL12, VL13 at ambient temperature solid line : MA, dashed line : TCBS 
$\mathbf{A}$
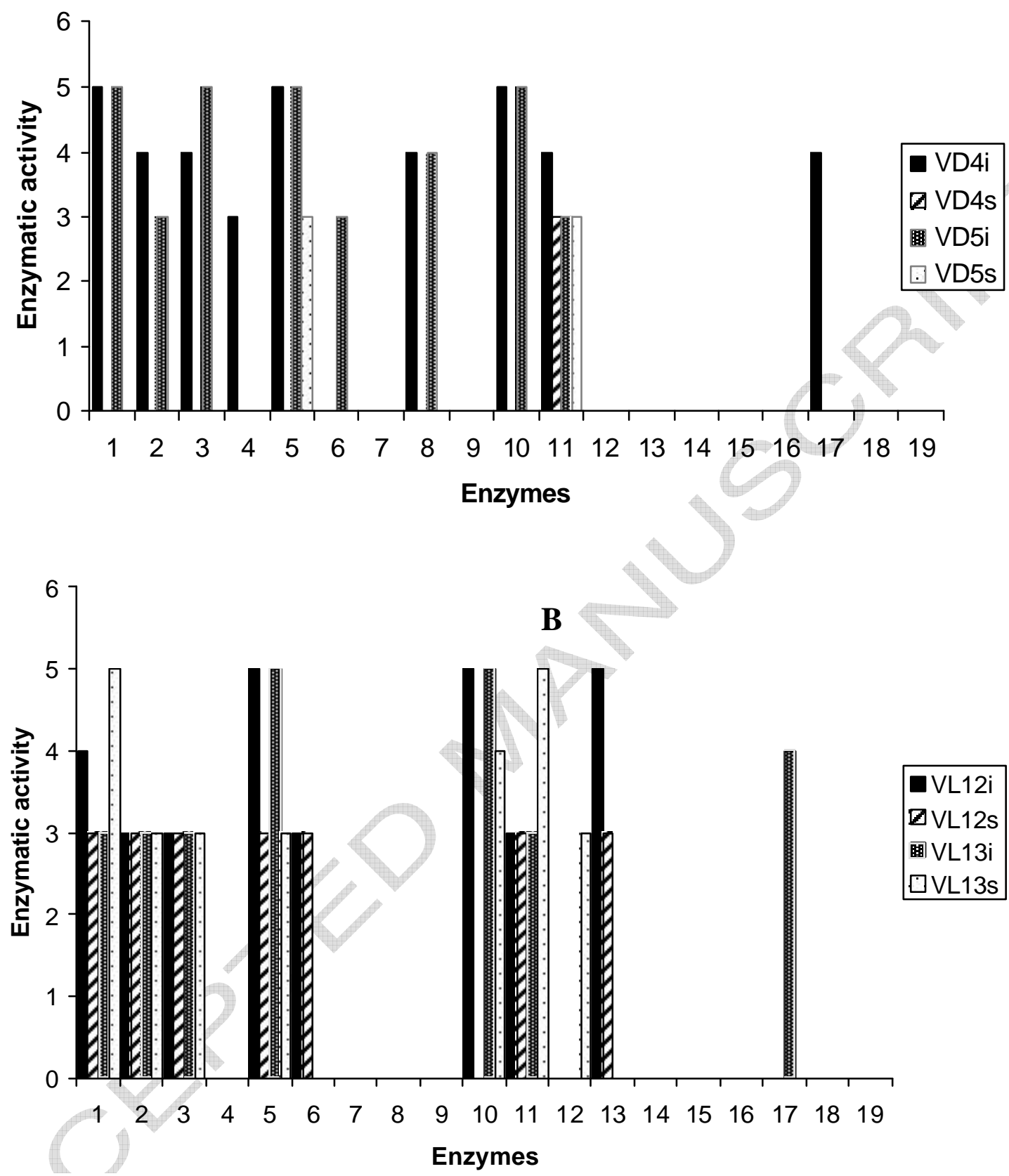

Fig 3. Changes in Api ZYM enzymatic profile of initial cells (not incubated in sea water) (i) and starved cells incubated in sea water (s) of Vibrio alginolyticus. (A): VD4 and VD5, (B) VL12 and VL13.

1: alkaline phosphatase , 2: C4 esterase, 3: C8 esterase lipase, 4: C14 lipase, 5: leucine arylamidase, 6: valine arylamidase, 7: cystine arylamidase, $8:$ trypsine, $9: \alpha$-chymotrypsine, 10 : acid phosphatase, 11: naphtol-AS-BI-phosphohydrolase, $12: \alpha$-galactosidase, $13: \beta$ galatosidase, $14: \beta$-glucoronidase, $15: \alpha$-glucosidase, $16: \beta$-glucosidase, $17:$ N-acetyl $\beta$ glucosaminidase, $18: \alpha$-mannosidase, $19: \alpha$ fucosidase. 


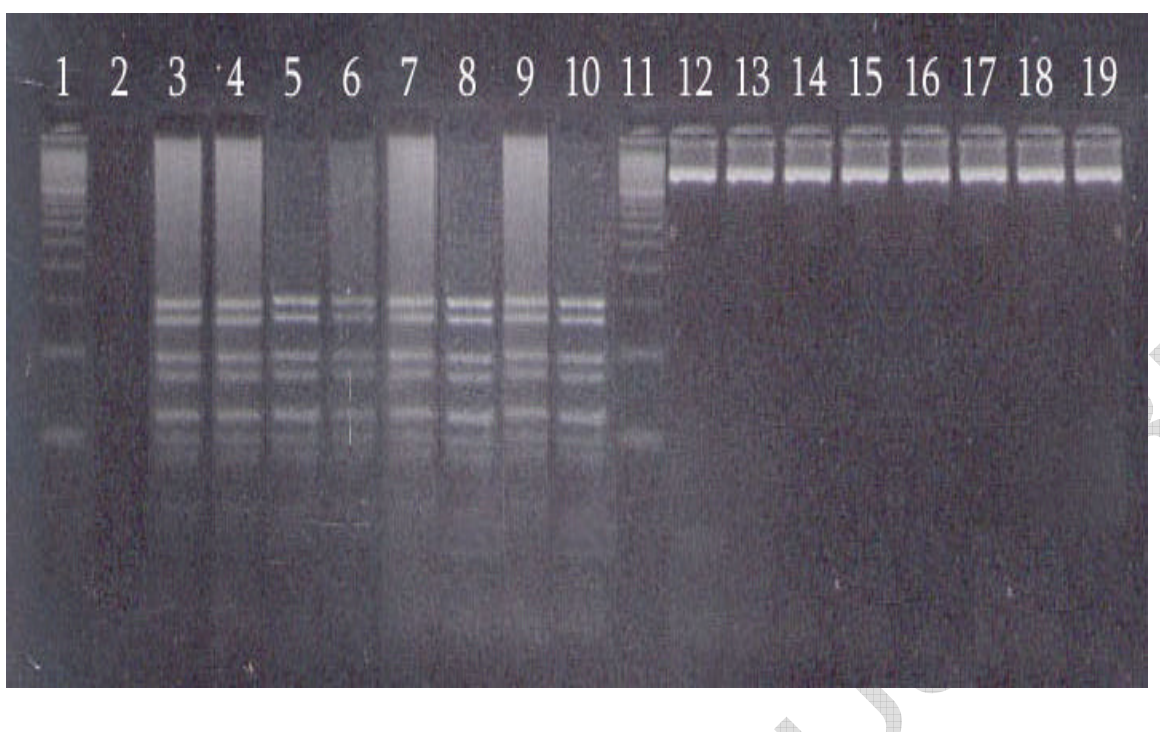

Fig 4. Overview of the patterns obtained after restriction of the amplified 16S rRNA gene with the enzyme HaeIII of $V$. alginolyticus strains. Lanes 1, 11, molecular size marker (100-bp ladder; Promega). 2, negative control. 3, 5, 7, 9 (respectively VD4, VD5, VL12 and VL13 not incubated in microcosms) 4, 6, 8, 10 (respectively VD4, VD5, VL12 and VL13 after 1 year of incubation in sea water microcosms) $12,13,14,15,16,17,18$ and 19 pattern at $1500 \mathrm{bp}$ of different forms of V. alginolyticus cited above. 